\title{
Desblache, L. (2019). Music and translation: New mediations in the digital age. London: Palgrave Macmillan. 407 pp.
}

Music translation today is a small but expanding field of study. While some scholars have recently begun to explore different intersections and connections between music and pioneering disciplines such as audiovisual translation (Gorlée, 2005; Minors, 2013; SusamSarajeva, 2008), few have dared to step into this field, in which most scholarly contributions have mainly been of a descriptive, didactic or empirical nature, and an in-depth exploration of musical influences across cultures has been absent to date. This is precisely what Music and Translation: New Mediations in the Digital Age intends to examine. It delves into "how translation, in its many senses, is shaping music today" (p. 4) and investigates the impact that music translation has on transforming societies across cultural borders and facilitating "communication between species" (p. 373).

In the context of ubiquitous twenty-first century music, which travels globally and instantaneously, the author has kept three main aims in mind: first, to expand the existing framework for understanding how music and translation are related; second, to survey existing studies on the many ways in which music is translated critically and, third, to offer indepth considerations on the creative aspects of music as a translational agent. These objectives entail, as mentioned in the introduction, exploring widely "how musical texts are translated, but also [investigating] how music and translation relate to each other" (pp. 8-9) beyond the analysis of song translation, which is normally at the heart of publications in the field of music translation.

The volume comprises ten chapters, framed by an introduction (Chapter 1, "Prelude"), which sets the tone for the book and introduces its wide scope, and a final chapter (Chapter 10, "Coda"), which opens a window on new research and field studies. Each chapter is followed by an independent long bibliography, which can serve as both a starting point for newcomers in the field of music translation and a useful complement for seasoned scholars. The interdisciplinary references included at the end of each chapter, as well as the useful name and subject indexes, are a testimony to the conceptual and epistemological richness of the volume.

One of the original features of the book is linked to its tripartite structure. Part I ("Music and Translation in a Global Context") comprises two chapters (Chapters 2 and 3), which are primarily definitional and conceptual. These chapters set the music scene in a global context and explore how music and translation interact and connect to one another. Popular concepts such as adaptation, mediation or transcreation are discussed here, while always keeping in mind different approaches to audience reception and cultural translation as tools of transformation. Part II ("Translating Music") involves three chapters (Chapters 4, 5 and 6), which focus on issues related to translation and musical texts. While song translation has recently been given more prominence in translation studies, mainly through practical manuals on song translation (Apter \& Herman, 2016; Low, 2017), it is not the only area to explore. One of the strengths of this book is precisely that it goes beyond proving a mere guide to song translation. Desblache aims to raise a broader awareness of the ample variety of translation modes and strategies that impact music and how it is received. Finally, Part III ("Music Translates") contains three chapters (Chapter 7, 8 and 9) and highlights "the translational 
power of music" (p. 10) and how it has been shaping not only human cultures, but also the relationship that humans have with the natural world.

Chapter 2, entitled "Music, Centres and Peripheries", shows how music translation generates new forms of what the author calls "community translation" (p. 19) at the dawn of the twentyfirst century. Desblache shows how audiences' interpretations of multilingual and multicultural products are shared collectively through opinions about the meanings of lyrics across borders, social contexts, cultures, identities and languages. She does so by discussing one of the first manifestation of translation through social media, namely the case of Teddy Afro's song "Jah Yasteseryal". The chapter focuses on the relationship between music and translation, emphasising both "the dominance of Anglo-Saxon models in the production and dissemination" (p. 42) of musical products and the cosmopolitan nature of music exchanges, which both impact their translation in different ways. Chapter 3, "Music and Translation Today", argues that "musicology and translation studies should be interconnected" (p. 58) and discusses the variety of definitions of music and translation in and beyond the field of music. Concepts such as transcreation, mediation, adaptation or transadaptation are considered in relation to translation, within the "specific scopes and practices" of a "mediated culture" ( $p$. 69), which is multimodal. In addition, Desblache outlines the historical trends of music reception in the Western world, highlighting how today music is "increasingly driven by audiences' responses" (p. 82). Music viewers and listeners are "prosumers", as they dictate the different modes of translation or even whether a product should be translated in the first place. The author presents a number of surveys which conclude, within the limit of their scope, that audiences seem eager for more song translations in live popular music events, such as festivals, where they are non-existent.

The next two chapters explore which musical texts are translated and which aspects of music can be translated. Chapter 4 ("What is Translated? Styles, Genres and More") focuses on nonreferential content. By introducing existing scholarship on musical hermeneutics and ekphrasis (Dayan's and Kramer's work in particular), Desblache considers the mediation of musical messages or messages about music across other art forms. More specifically, she discusses how style, genre, rhythm and other musical components can be translated. Chapter 5 ("What is Translated: Vocal Music, Voice and More") surveys European traditions of vocal music translation, showing that lyrics transfer has always been inconsistent, particularly in popular music. It also emphasises the importance of the quality and musicality of a voice and how these aspects mediate in contemporary media products. Chapter 6 ("How is Music Translated? Mapping the Landscape of Music Translation") reviews the modalities and strategies of musical translation, focusing mainly on vocal music and acknowledging existing research in this area. It highlights the contrasting expectations and possibilities of translation in spaces as different as, for instance, live performance, radio or video game settings. A section within this chapter is also devoted to the complex rapport of music with (media) accessibility.

Music changes lives. Its power of transformation "has certainly been increasingly acknowledged in the last few decades" (p. 266), as is evoked in Chapters 7 ("Music and Human Activities"), 8 ("In and Beyond the Material") and 9 ("Music and the Natural World"). These last chapters explore "the translational ability" (p. 267) of music in relation to emotion, sensorial expression, and a social as well as environmental sense of belonging. Humans are not the only agents that produce and respond to meaning: computers, rocks or musical instruments, as thinkers such as Latour (2005) have argued, can also be considered "mediators" (p. 271). Desblache argues potently that, as a consequence, new forms of 
translation are needed to translate beyond the verbal and that music, as a performative and intertextual form by excellence, is a privileged medium for explorative forms of translation. Therefore, music has played - and still plays - a crucial role in human societies across cultural borders, improving people's lives and accompanying social and political movements throughout history, which is why it can be perceived as a threat by political or religious establishments. Finally, the interconnection between music and nature is the object of the last chapter, in which Desblache tackles this unexplored area. Animal and environmental sounds have shaped human cultures and environments. The author suggests different ways in which music and nature interrelate today, such as bird song imitation used in Western music, fostering "human attempts to engage with the non human" (p. 350).

Overall, this book is a tour de force of scholarship in the area of music and translation. It covers a lot of ground, surveying existing research and delving into unexplored territories. Its interdisciplinary theoretical references and the diverse musical examples that sustain and illustrate its arguments stretch present scholarship into new areas of discoveries. Inevitably, in a work of such wide scope, some areas could have been explored in more depth, particularly in Chapter 6, which provides an overview of music translation in different media. For example, song translation in films, an area still under-researched, deserves more extensive development, as does the section on DVD, Blu-Ray and video games.

Nevertheless, as the author states, the intention of this book was not merely to survey existing research but to "be ear-opening for translators and mind-expanding for musicians" (p. 11). This is exactly what this monograph does. Enlightening, engaging, informative, illuminating and original, Music and Translation: New Mediations in the Digital Age follows in the footsteps of Desblache's previous works (2013, 2018 and 2019) and proves once again that she is one of the main experts in the field of music and translation today.

\section{References}

Apter, R., \& Herman, M. (2016). Translating for singing: The theory, art and craft of translating lyrics. London: Bloomsbury.

Desblache, L. (2013). Translating music. Retrieved from http://www.translatingmusic.com/index.html Desblache, L. (2018). Translation of music. In C. Sin-wai (Ed.), An encyclopedia of practical translation and interpreting (pp. 297-324). Hong Kong: The Chinese University Press.

Desblache, L. (2019). Music. In Washbourne \& Van Wyke (Ed.), The Routledge handbook of literary translation (pp. 282-297). London: Routledge.

Gorlée, D. (2005). Song and significance: Virtues and vices of vocal translation. Amsterdam: Rodopi.

Latour, B. (2005). Reassembling the social: An introduction to actor-network-theory. Oxford: Oxford University Press.

Low, P. (2017). Translating song: Lyrics and texts. London: Routledge.

Minors, H. (2013). Music, Text and Translation. London: Bloomsbury

Susam-Sarajeva, Ş. (2008). Translation and Music: Changing perspectives, frameworks and significance. In Susam-Sarajeva (Ed.), Translation and music, The translator, 14 (2), 187-200. Manchester: St Jerome.

\section{Belén Cruz Durán}

Universidad de Málaga, Spain

belencruzduran@gmail.com 